\title{
Highway to Hell: Hunting Evil Creatures with the Winchester Boys
}

\author{
Elisabete Lopes
}

\begin{abstract}
Supernatural is a contemporary TV series that is rife with gothic undertones. The main characters, the Winchester boys, do not correspond to the usual hero prototype, who generally displays some type of super power. Actually, they are two brothers who ride in their black Impala (their true home) and believe to be on a mission to save people's lives and do away with the monsters afflicting them. The only thing they carry in the boot of the Impala is a suitcase with holy water, salt, stakes and fake IDs.

Sam and Dean (the Winchester brothers) did not have an ordinary childhood: from a young age they were introduced by their father to the hunter's lifestyle. Moreover, their mother died at the hands of some mysterious yellow-eyed demon.

In fact, Supernatural shows us that monsters abound in contemporary landscape: werewolves, ghosts, vampires, witches, and demons. In truth, all of these evil creatures can be said to mirror, to a certain extent, the fears tied in with the global crisis that the world is undergoing these days. In this light, we can say that the Winchester boys have some serious challenges ahead, since Supernatural showcases this crisis as a sign of an impending apocalypse. In addition, the brothers find out that one of them is doomed to be the vessel for the devil.

Given the sinister omens that Supernatural hints at, it is then important to raise some questions: What kind of hero is liable to emerge in a dystopian world? What kind of metaphors do monsters embody? What challenges must these brothers ultimately face in order to stay alive in a predatory environment? These are some of the questions that this paper aims at addressing, in keeping with the idea that the gothic still works as a mirror for our daily fears and anxieties.
\end{abstract}

Key Words: Supernatural, Winchester boys, evil creatures, monsters, crisis, devil, dystopian world.

$* * * * *$

\section{On the road with Dean and Sam}

Supernatural is a contemporary TV series that is rife with gothic undertones and which has debuted on the 13th September 2005. The main characters, the Winchester boys, do not correspond to the usual hero prototype, who generally displays some type of super power. Actually, they are two brothers who ride in their black 67 Chevy Impala and believe to be on a mission to save people's lives and do away with the monsters afflicting them. The only thing they carry in the boot of the Impala is a suitcase with holy water, salt, stakes and fake IDs. 
Initially the show had been planned to consist of a series of stand-alone episodes where the brothers would research and hunt down a different creature every week, but afterwards it began to bet on a continuous narrative that involved the more intimate and personal side of the heroes. As a result, alongside the monster search, the viewer could also have a glimpse of the past of the Winchesters as well as their plans for the future. Kripke, the creator of the characters remarks:

When we started out, we were going to make a horror movie every week. It was about the monsters, and it was about Hook Man and Bloody Mary and the urban legends and the boys honestly, in the beginning, Sam and Dean were an engine to get us in and out of different horror movies every week. $^{1}$

We learn from this statement that Kripke's intention had always been to transform a series about supernatural events into a series that would also revolve around family bonds anchored upon friendship and faithfulness.

The two brothers drive through America in search of cases to solve, being constantly on the road, recalling Jack Kerouac's 50s novel On the Road, which has also two male protagonists. ${ }^{2}$ While on the road, the Winchesters hunt demons, they perform exorcisms and other cleansing rituals. Wendigos, vengeful ghosts belonging to traditional folklore (bloody Mary, the Woman in White), witches, vampires, werewolves, killer clowns, shape-shifters, hell hounds, sirens, pagan gods and demons are some of the creatures they come up against in each one of the episodes. While on their undercover missions, they often disguise themselves as journalists, FBI agents, priests, university students or insurance investigators.

The black Impala also plays an important role in Supernatural. Apart from being a weapon's storage, it also works as a kind of home, an intimate refuge for the brothers. Metaphorically, it embodies the black horse of a cowboy, hence standing for a symbol of freedom and independence. Often episodes end with a view of a stretched open road losing itself in the horizon, the camera focus aimed at the black roaring vehicle cruising the road, a fact that calls to our mind images from the old classic westerns in which the lonely cowboy departed riding on his horse, heading towards the sunset. The family name chosen by Kripke Winchester- is also highly suggestive, since it is also the brand of a weapon manufacturer.

The soundtrack is also a very alluring aspect that characterizes this series. It recovers several tracks of rock and roll from the past. The song 'Highway to Hell,' which I chose to illustrate the title of this paper, appears for the first time in the pilot series and from then on, it will become a kind of brand for it. As a matter of fact, the Winchester's journey across the American landscape can be defined as a 
treacherous path, a highway that can easily take the wrong turn thus leading them into the pit of hell.

The spaces the two brothers explore in their supernatural ramblings are also permeated by gothic motifs. Some suggestive examples are the mental hospital they investigate in 'Asylum', the haunted house they come across with in 'Hell House', the derelict town in 'Croatoan,' or the claustrophobic tunnels in 'No Exit.' Although the show features some episodes which take place in rural areas, the main focus of paranormal activity is located in the suburbs, where the brothers try to figure out the skeletons families hide in the closet. As Bernice Murphy claims,

the Suburban Gothic is a sub-genre concerned, first and foremost, with playing upon the lingering suspicion that even the most ordinary-looking neighbourhood, or house, or family, has something to hide, and no matter how calm and settled a place looks, it is only ever a moment away from dramatic (and generally sinister) incident. ${ }^{3}$

Interestingly, in Supernatural, the family business which primarily deals with things that fit in the realm of the uncanny, turns into something which is very natural and 'homely' to the brothers. As Jensen Randall remarks, 'Horror stories involve something strange, out of place, unseen or unknown, something that makes our skin crawl and our spines tingle. What we regard as the supernatural realm is for Sam and Dean a part of nature. The supernatural has thus been naturalized. ${ }^{4}$

Taking into account the nature of the topics tackled by Supernatural, it is then important to raise some questions: What kind of hero is liable to emerge in a dystopian world? What kind of metaphors do monsters embody? What challenges must these brothers ultimately face in order to stay alive in a predatory environment? These are some of the questions that this paper aims at addressing, in keeping with the idea that 'The best horror stories... are like a funhouse mirror held up to our darkest fears and deepest insecurities. ${ }^{5}$

\section{The wise geek and the rebel in leather jacket}

Apart from delving into gothic atmospheres and spaces, offering the spectator a balanced dose of horror and terror, the success of this series heavily relies upon the chemistry which is generated between the two brothers, each one of them with a completely different personality.

Despite being the older brother, Dean is certainly more laidback and the one who, against all odds, still keeps a sharp sense of humour when things go awry. When it comes to love, one can easily understand that Dean tries to avoid any kind of commitment and prefers to engage in one-night stands, bonds which do not demand any emotional involvement or personal responsibility. He is the rebel without a cause, the loner handsome boy who girls meet in a bar, wearing his 
leather jacket and making easy conversation. In the "The Usual Suspects," the older brother describes himself this way: 'I'm an Aquarius. I enjoy sunsets, long walks on the beach and frisky women. ${ }^{6}$ Even though he cultivates this though guy persona, some episodes reveal his most sensitive side, especially when it comes to children.

Conversely, Sam is more responsible, discrete, polite, faithful and courteous to women, as the episodes 'Woman in White' or 'Provenance' illustrate. Sam's naiveté is confirmed by Dean when he comments, 'Come on man. I know Sam, ok? Better than anyone. He's got more of a conscience than I do. I mean the guy feels guilty searching the internet porn. ${ }^{7} \quad$ Sam is also displayed before the audiences as the brother who is more understanding and compassionate towards the creatures they hunt. He is the one who is prone to show clemency towards the others who are different, the so-called monsters. Somehow he feels that due to the fact that he has been brought up to fulfill his destiny as a hunter, he almost did not have any chance to weave his life otherwise. The destiny has imposed itself upon his life as something stronger, almost as something inherited from a generation of hunters, like once it had happened to his mother and father. Deep down inside, he knows that those creatures have been born like that, or have been created without having the opportunity to exercise their free will. Therefore, he believes that each one of this creatures, like himself, were forced to embrace a life that had not been wished for nor idealized.

In 'Bloodlust' Sam and Dean come across a vampire coven, whose members claim to be vegetarian, that is to say, they feed off animal's blood instead of human's. Sam faces a dilemma because, having been previously saved by a female vampire from this coven, he instinctively senses that she represents no harm to him, his brother and other humans. However, and according to the hunter's code, vampires are among those creatures that need to be exterminated as they constitute a potential threat to human safety. Dean, and another fierce hunter they meet in this episode think that the woman should be killed as well as the rest of the group. Sam tries to convince his brother that things are not so black and white. Despite being a vampire, that young female saved his life without even trying to suck his blood.

Moreover, when the brothers investigate a case of apparent divine justice in 'Houses of the Holy,' Sam is the one who shows faith, since he is willing to believe in angels and miracles. On the other hand, Dean keeps a skeptic position which will be strongly shaken in the end of the episode, when he has to come to terms with the fact that sometimes angels do seem to be overlooking the earth and exerting justice.

Nevertheless, in Supernatural he often displays a tendency to have a crush on dangerous female characters. In 'Heart' he involves himself with Madison, a beautiful werewolf girl who, according to Dean's words, is 'a human by day, [but] a freak animal killing machine by moonlight.. ${ }^{8}$ In the end of the episode, Sam will have to shoot her, so as to put an end to the cycle of killings. Later on, in 
'Scarecrow,' he also feels attracted to Meg, who is a demon servant. In 'Dream a Little Dream of Me' Sam almost succumbs to the charms of Bela Talbot, a clever thief who is capable of doing anything to pursue her goals, regardless the fact that she can be responsible for someone's death along the way. Furthermore, in the fourth season he will fall in love with Ruby, a demon who convinces him that she is on his side, but who, eventually is only working on her behalf and harms him by instigating his addiction to demon blood.

Thus, although initially Dean seems to be more outgoing and daring, throughout the series, he will go through a set of transformations, ending up by becoming more mature. After the older Winchester brother has spent some time in hell, and then in the wilderness of the purgatory, he returns somehow wiser and more introspective. He believes that he has experienced something that no human being should ever need to experience. At some point, the viewer can sense in Dean's look the burden of fear and horror that his words can't express.

\section{Doomed Sam}

During season four, in 'Metamorphosis,' Sam learns that he has been infected with demonic blood and that he somehow carries the mark of doom. This blood was given to him by Azazel, known as the yellow-eyed demon, whose ultimate goal is to produce an army of gifted kids to serve the purposes of evil. Sam finds out that his psychic powers and his premonitions stem precisely from this demon blood ingestion that occurred when he was still a baby. Likewise, in 'Croatoan,' Sam realizes he is immune to the deadly demon virus, and he starts to worry about his condition. By that time, deep down inside, he is sure that he is somehow different. Finally, in 'Lucifer Rising,' appalled, he tells his brother, 'I've got demon blood in me, Dean. I'm a whole new level of freak!' ${ }^{9}$ At that moment, Sam realizes that he has a connection with the specimens they hunt since he is also a monster, an outsider, someone that, according to his words, belongs to a new generation of misfits. However, things get worse for the younger brother, when he is informed that Lucifer has plans for him.

Indeed, further ahead, the young Winchester will realize that he is kind of doomed to be Lucifer's human vessel, so the fact that the demonic blood gives him extra strength means that his whole life has been a kind of a walk towards the fulfillment of a tragic destiny. Lucifer wants a strong healthy male body that he can use to accomplish his mission of dominating the human world. Actually, in 'The End,' Dean is tormented by a hallucination in which Sam appears to him as Lucifer, wearing a white tuxedo and holding a rose, in a cemetery. The subtlety of this image lies on the fact that Lucifer appears to feed on innocence; apparently, those who appear harmless and docile (like Sam) are the ones who constitute the ultimate devil's prey, as they represent a bigger challenge. This suggestive image also hints at one emblematic trope of the gothic, the so-called döppelganger. Samas-Lucifer tells Dean that, regardless of the choices he makes in life, they will 
always end up there in that same spot, time and time again. The philosophical premise implied here is that good and evil are indissociable, meaning that one will not exist without the other.

\section{The Hunter's Way}

The spectator can fully understand the relevance of the family business, when, in 'Dead Man's Blood,' John Winchester informs Sam that his college funds were all spent on ammunition.

Dean and Sam are perfectly aware that they were raised within a dysfunctional family. Hunters just don't have the privilege of having a normal day-to-day routine. Likewise, they don't know what it is like to have a normal childhood. At some point, Dean vents his disappointment concerning the life they have been leading:

That is exactly why our lives suck. I mean, come on, we hunt monsters! What the hell? I mean, normal people, they see a monster, and they run. But not us, no, no, no, we search out things that want to kill us. Or eat us! You know who does that? Crazy people! We are insane! You know, and then there's the bad diner food and then the skeevy motel rooms and then the truckstop waitress with the bizarre rash. I mean, who wants this life, Sam? Seriously? Do you actually like being stuck in a car with me eight hours a day, every single day? I don't think so! ${ }^{10}$

As previously mentioned, family bonds constitute a kind of holy ground for Eric Kripke. From the beginning of the show, Supernatural's creator was adamant in putting emphasis on family matters. In an interview, he stated,

It was a stressful position to be in to have one brother that was chosen by angels and one that was chosen by Lucifer that was in the same family. The semantic of the show has always been that families overcome everything. And if the show ever had one message, it was that nothing is more important than the bonds of family and it's more important than even the bonds of Heaven and Hell. ${ }^{11}$

Above all, in Supernatural, the concept of family business implies sacrifices. In 'Crossroad Blues' John strikes a deal with a demon named Azazel in order to save Dean's life. At that time Dean is at the hospital severely wounded and fighting for his life following a tough mission. Later on, in 'All Hell Breaks Loose,' it is up to Dean to go back to the crossroads and plead for a deal with a female demon, who gives him a year in exchange for Sam's life. Coincidentally, the brothers also 
discover that sacrifice runs in the family's blood because in the episode 'In the Beginning' Dean travels back in time and becomes acquainted with the fact that his mother, Mary Campbell, had also made a pact with the yellow-eyed demon, unbeknown of the tragic consequences underlining her act. ${ }^{12}$

In 'Nightmare' Sam acknowledges this fact when he declares that their family dark spots are 'pretty dark.' ${ }^{13}$ In this way, in Supernatural it is not only the American landscape that is haunted, but the Winchester family past as well.

\section{Supernatural takes a walk on the metafictional side}

Apart from being a show that brings the gothic tropes back to the TV screen, Supernatural constitutes a visual space where metatextuality is inscribed. Throughout the series, the spectator is liable to identify references to popular films and real-life events. In this way, the show manages to engage in a permanent dialogue with its viewers. Interestingly, almost all of these references appear under an ironic register. One of the most striking references is the scene in which the Winchesters parody Lieu-tenant Horatio Caine from C.S.I Miami. Both bothers strike the FBI agent's well-known pose: spread legs, a hand at the waist and the sunglasses on. In 'No Exit' Dean teases Sam, pretending to tell him about a new case, 'Young girl got kidnapped by an evil cult.' When Sam asks him who the girl is, he just replies that it is Katie Holmes. Surprisingly, even the show itself falls prey to parody and indulges in strategies that are grounded on a kind of mise en abyme. For instance, in 'The Monster at the End of this Book,' Sam and Dean face an awkward situation in which they have to deal with the fact that they are book characters. Supernatural is actually a novel series written by someone named Chuck. In the course of the episode they will find out that the writer turns out to be a prophet committed to tell some sort of biblical account that involves the two brothers as heroes. To their astonishment, they even discover that they have a community of fans. In other hilarious episode, 'The French Mistake,' the brothers merge into an alternative reality where everybody takes them for actors, Jensen Ackles and Jared Padalecki, who play the role of the Winchesters on a TV show. Unexpectedly caught up in this strange reality, the brothers are forced to act in one of the Supernatural sets, a fact that makes them feel like strangers in a strange land. Both Sam and Dean find this B-side of reality completely outlandish and out of touch with their 'real jobs' in their supposedly 'real lives.' After all, they are hunters not some guys who became famous due to a paranormal TV show. Therefore, by engaging in self-parody, Supernatural aims at stimulating the interaction between the public and fiction and, at the same time, this kind of interplay works as if it were a reward to the audiences, a kind of 'thank you' for watching the show.

\section{Conclusion}


This paranormal TV series shows us that monsters - werewolves, vampires, tricksters, ghosts, witches and demons - abound in the contemporary landscape. In truth, all of these evil creatures can be said to mirror the fears tied in with the global crisis which the world is currently undergoing. Supernatural is the living evidence that the gothic is still alive and kicking. In this perspective, Sam and Dean aren't just two young hunters who seek to protect humans from monsters, they stand not only as a mirror for one another, but also as a mirror to the audience who is also eager to wipe those threats out of the map. In a way, the Winchester's road trip encompasses an existential essence with which we all are likely to connect. All in all, there is a route 66 reserved for all us, we all have our personal demons and fears that need to be fought along the way.

\section{Notes}

1 Eric Kripke, Viewed 8 Jan, 2013, < http://voices.yahoo.com/interview-erickripke-talks-essential-supernatural-11949431.html>.

${ }^{2}$ Actually, one of them is also named Dean, and the other is Sal.

${ }^{3}$ Bernice Murphy, The Suburban Gothic in American Popular Culture, (New York: MacMillan, 2009), 2.

4 Jensen, M. Randall. 'What's Supernatural about Supernatural?' In The Hunt: Unauthorized Essays on Supernatural, (Dallas: BenBella Books, 2009), 30.

${ }^{5}$ Gregory Stevenson, 'Horror, Humanity and the Demon in the Mirror,' In The Hunt: Unauthorized Essays on Supernatural, (Dallas: BenBella Books, 2009), 4041.

6 'The Usual Suspects,' (2.07).

7 'Hunted' (2.10).

8 'Heart,' (2.17).

9 'Lucifer Rising,' (4.22).

10 'Yellow Fever,' (4.06).

${ }^{11}$ Eric Kripke, Viewed 8 Jan, 2013, < http://voices.yahoo.com/interview-erickripke-talks-essential-supernatural-11949431.html>.

${ }^{12}$ Owing to this pact, Mary Campbell compromises Sam's future, turning him into a cursed child.

13 'Nightmare,' (1.14). 


\section{Bibliography}

Kripke, Eric. <http://voices.yahoo.com/interview-eric-kripke-talks-essentialsupernatural-11949431.html>. Accessed 8 Jan, 2013.

Jensen, M. Randall. 'What's Supernatural about Supernatural?' In In The Hunt: Unauthorized Essays on Supernatural, edited by Supernatural TV, 27-38. Dallas: BenBella Books, 2009.

Murphy, Bernice. The Suburban Gothic in American Popular Culture. New York: MacMillan, 2009.

Stevenson, Gregory. 'Horror, Humanity and the Demon in the Mirror.' In In The Hunt: Unauthorized Essays on Supernatural, edited by Supernatural TV, 39-52. Dallas: BenBella Books, 2009.

Supernatural. Season 3, Episode no.16, 'No Rest for the Wicked,' first broadcast 15 May 2008 by CW. Directed by Kim Manners.

Supernatural. Season 1, Episode no.10, 'Asylum,' first broadcast 22 Nov.2005 by CW. Directed by Guy Norman Bee.

Supernatural. Season 1, Episode no.17, 'Hell House,' first broadcast 30 Mar.2006 by CW. Directed by Chris Long.

Supernatural. Season 2, Episode no.9, 'Croatoan,' first broadcast 7 Dec.2006 by CW. Directed by Robert Singer.

Supernatural. Season 2, Episode no.6, 'No Exit,' first broadcast 2 Nov.2006 by CW. Directed by Kim Manners.

Supernatural. Season 2, Episode no.7, 'The Usual Suspects,' first broadcast 9 Nov.2006 by CW. Directed by Mike Rohl.

Supernatural. Season 2, Episode no.10, 'Hunted,' first broadcast 11 Jan. 2007 by CW. Directed by Rachel Talalay.

Supernatural. Season 1, Episode no.1, 'Woman in White,' first broadcast 13 Sep. 2005 by CW. Directed by David Nutter.

Supernatural. Season 1, Episode no.19, 'Provenance,' first broadcast 13 Apr. 2006 by CW. Directed by Philip Sgriccia.

Supernatural. Season 2, Episode no.3, 'Bloodlust,' first broadcast 12 Oct. 2006 by CW. Directed by Robert Singer. 
Supernatural. Season 2, Episode no.13, 'Houses of the Holy,' first broadcast 1 Fev. 2007 by CW. Directed by Kim Manners .

Supernatural. Season 2, Episode no.17, 'Heart,' first broadcast 22 Mar. 2007 by CW. Directed by Kim Manners.

Supernatural. Season 1, Episode no.11, 'Scarecrow,' first broadcast 10 Jan. 2006 by CW. Directed by Kim Manners.

Supernatural. Season 3, Episode no.10, 'Dream a Little Dream of Me,' first broadcast 7 Fev. 2008 by CW. Directed by Steve Boyum.

Supernatural. Season 1, Episode no.9, 'Home,' first broadcast 15 Nov. 2005 by CW. Directed by Ken Girotti.

Supernatural. Season 4, Episode no.22, 'Lucifer Rising,' first broadcast 14 May 2009 by CW. Directed by Eric Kripke.

Supernatural. Season 5, Episode no.4, 'The End,' first broadcast 1 Oct. 2009 by CW. Directed by Steve Boyum.

Supernatural. Season 1, Episode no.20, 'Dead Man's Blood,' first broadcast 20 Apr. 2006 by CW. Directed by Tommy Wharmby.

Supernatural. Season 4, Episode no.6, 'Yellow Fever,' first broadcast 23 Oct. 2008 by CW. Directed by Philip Sgriccia.

Supernatural. Season 2, Episode no.8, 'Crossroad Blues,' first broadcast 16 Nov. 2006 by CW. Directed by Steve Boyum.

Supernatural. Season 2, Episode no.3, 'All Hell Breaks Loose,' first broadcast 12 Oct. 2006 by CW. Directed by Robert Singer .

Supernatural. Season 2, Episode no.22, 'All Hell Breaks Loose-II,' first broadcast 17 May 2007 by CW. Directed by Robert Singer.

Supernatural. Season 1, Episode no.14, 'Nightmare,' first broadcast 7 Fev. 2006 by CW. Directed by Philip Sgriccia.

Supernatural. Season 4, Episode no.18, 'The Monster at the End of this Book,' first broadcast 2 Apr. 2009 by CW. Directed by Mike Rohl.

Elisabete Lopes is an English Language Lecturer at the Polytechnic Institute of Setúbal. Both her Master's degree and her PhD thesis were in the field of Gothic studies. Her current areas of research are related to the Gothic genre, namely women's studies and visual culture. 
